\title{
Effects of Organizational Culture, Motivation and Work Discipline on Employee Performance with Leadership as Intervening Variables in Tanjungpinang District
}

\author{
Mahnizar Fachruddin Indrayani Sri Yanti \\ Faculty of Economics, Batam University, Riau Islands, Indonesia
}

\begin{abstract}
This study aims to determine the effect of Organizational Culture, Motivation and Discipline on Performance and Leadership as an intervening variable. The hypothesis put forward by Organizational Culture gives an effect on Leadership, Motivation gives effect to Leadership, Discipline gives effect to Leadership, Organizational Culture gives effect to Performance, Motivation gives effect to Performance, Discipline gives effect to Performance and Leadership gives effect to Performance. The sample in this study were all employees in Tanjung pinang city and sub-districts below. The number of samples used were 95 respondents. The data in this study were obtained by distributing questionnaires filled out by respondents. The data obtained were analyzed using data analysis techniques with PLS 2.9 rock software. R Square Culture of Organization, Motivation, Discipline, and Leadership values indicate $89.0 \%$. Thus, it can be stated that the effect of Culture of Organization, Motivation, Discipline, and Leadership, amounting to $89.0 \%$, the remaining $11 \%$ is the contribution of other variables that have not been included in this study. The effects of Culture of Organization, Motivation, Discipline, and Leadership have a variety of significant positive and not significant, but the contribution of each in R square remains above $50 \%$, this shows the research model is quite good.
\end{abstract}

Keywords: Culture of Organization, Motivation, Discipline, Leadership and Performance

DOI: $10.7176 / \mathrm{EJBM} / 12-21-03$

Publication date:July $31^{\text {st }} 2020$

\section{Introduction}

In Indonesia, the number of civil servants reaches no less than five million people. From that number, according to sources Based on data from the National Personnel Agency, the number of civil servants as of December 31, 2018 was 4,185,503 with details of 939,236 civil servants serving at the Central Agency (22.44\%) and 3,246,267 PNS serving at Regional Agencies (77.56\%). From the large number of civil servants there are still many employees who do not have a good organizational culture and have low productivity values. This is evidenced by the fact that there are still many employees absent during office hours or after national holidays, so this is still a problem in several government agencies. in the central government and in regional government. This indicates that organizational attitudes and culture among civil servants have not grown and become an awareness for each individual or collective. A fairly complex challenge is how to change the old organizational culture that is no longer in line with the values of the new organizational culture of all employees at their own desires. voluntary and employee participation. People will not change by themselves just because they are ordered and will only change if they want to voluntarily, and consciously. Improving the performance of civil servants must of course be oriented to improving organizational culture. So that government officials will be created that are professional and productive.

Employee performance will be good and work seriously if they have high motivation. If the employee has a positive motivation then he will show interest, have attention, and want to participate in a task or activity. The success of employees in carrying out tasks due to encouragement or motivation as evidence that what employees do in accordance with the responsibilities in carrying out work. employees who are motivated to work will improve their performance. With the existing work motivation, he will work voluntarily, which in turn can increase employee productivity.

Theoretically as has been explained above that the performance of an employee can be influenced by several factors or variables including organizational culture, motivation, discipline and leadership. Based on the above problems, research needs to be done whether the factors of Organizational Culture, Motivation, discipline and leadership can also affect employee performance. The results of the study are expected to identify deficiencies owned by Tanjungpinang Kota District where researchers take research samples to provide the best solutions related to the Effect of Organizational Culture, Motivation, discipline and leadership on Performance in improving Employee Performance. Where this research will be conducted in the District of Tanjungpinang City.

\subsection{Formulation of the problem}

The following problem formulations in this study are as follows:

1. Is there a cultural influence on leadership? 
2. What is the effect of the effect on leadership?

3 . Are there effects of work discipline on leadership?

4. What is the effect of culture on employee performance?

5 . What is the effect of the effect on employee performance?

6. Is it related to the effect of work discipline on employee performance?

7. What has the effect of leadership on employee performance?

\section{Theoretical Basis}

\subsection{Organizational Culture Theory}

According to (Tampubolon, 2004) organizational culture is a pattern of rationale for determining, determining or developing organizational members in overcoming problems by adapting from outside and integrating into the organization so that employees can work carefully, and also benefit employees for their perceptions, thoughts, and feelings in relationships. In principle, organizational culture becomes the foundation for all employees or team members in achieving the organization's final goals, and organizational culture can be uncertain regarding the safety of employees in carrying out organizational functions. Whereas Randolph and Blackbum in (Tampubolon, 2004) state corporate culture as a set of key values, beliefs, and understandings made by and for members of the organization. Organizational culture and company culture are interrelated because both of them are related to each other's specific culture such as management style and management system and so on, but all are still in the organization's organizational settings. Some of the above understanding can be concluded that organizational culture is a system of mutual agreement of values, norms of whether the behavior that applies in an organization that is the basis of relationships for all employees, the increasing nature and relationship between an organization and its organization. Thus, between one organization and other organizations have different habits with both moving in the same field of business activity.

\subsection{Motivation Theory}

According to (Hasibuan, 2012) the word motivation comes from the Latin movere which means encouragement or move. Meanwhile, if it is associated with human resource management, then this motivation questions about how to be able to direct the power and potential of subordinates to want to work productively so that they can reach the set standards and achieve the goals set. According to (A. A. A. P. Mangkunegara, 2016) Motive is an encouragement in employees that needs to be met so that employees can adjust to their environment, while motivation is a condition that moves employees to be able to achieve the goals of their motives. According to Hasibuan, quoted by (Sutrischastini \& Riyanto, 2015) stated that motivation is the provision of movement that creates the excitement of one's work, so that they want to work together productively to achieve and realize the specified goals. Based on the theory above, it can be concluded that motivation is as a power resource that drives and controls human behavior. There are principles that must be implemented in motivating employees, namely: the principle of participation, the principle of communication, the principle of recognizing subordinate share, the principle of delegating authority and the principle of giving attention. In carrying out these principles, superiors and subordinates must have a fairly good interaction in conducting two-way communication to inspire each other's opinions in achieving common goals in the organization, the role of superiors in motivating employees is very important in realizing employees who are able to work productively with full responsibility answer. One reason is because employee motivation is a very important aspect in maintaining and developing human resources.

\subsection{Disciplinary Theory}

Discipline is the most important operational function of human resource management because the better employee discipline, the better the performance can be achieved. Without good discipline, it is difficult for organizations to achieve optimal results. In the world of work discipline is one's awareness and willingness to obey all company regulations and applicable social norms. According to Singodimejdo in (Sutrisno, 2010), discipline is an attitude of willingness and willingness to obey and obey the norms of regulations that apply around it. Furthermore, according to (Hasibuan, 2012) stated that discipline is the sixth operative function of Human Resource Management. Discipline is the most important HRM operative function because the better employee discipline is, the higher work performance can be achieved. While Keith Davis's translation of Agus Dharma (Keith, 2010) revealed that: "Management's actions to encourage the implementation of organizational standards, this is a training that leads to efforts to justify and involve employees' knowledge, attitudes and behavior so that there is a willingness in employees to go to work and even better achievements ". From some of the above opinions, it can be concluded that work discipline is a person's behavior in obeying the rules and procedures of work in accordance with those set by the organization both written and unwritten so that each job can run smoothly and employees can achieve better work performance. 


\subsection{Leadership Theory}

According to (Hasibuan, 2012) a leader is someone with leadership authority directing his subordinates to do part of their work in achieving goals. So that leadership is someone who has the nature to be able to use his authority to be able to direct his subordinates to do some of his work in achieving organizational goals. According to (Rivai \& Mulyadi, 2003), leadership is basically involving other people, involving uneven distribution of power between leaders and group members, mobilizing abilities by using various forms of power to influence the behavior of subordinates, and concerning values. Four general traits that have an influence on the success of organizational leadership, namely: (1) intelligence, (2) maturity, (3) self-motivation and achievement drive, and (4) attitude of human relations. Meanwhile, according to (Bangun, 2012) states leadership as a psychological process in accepting the responsibility of the task, self, and the fate of others, from some of the definitions of leadership, it can be concluded that leadership is an ability to influence enthusiasm, enthusiasm, security, work quality and organizational performance, and the ability to play a role in encouraging individuals and groups to achieve organizational goals. Someone who occupies the position of leader must be able to increase the effectiveness of his leadership with high ability to use a situational style which means different styles in different situations and conditions.

\subsection{Performance Theory}

Anwar (A. P. Mangkunegara \& Prabu, 2015) stated the definition of employee performance is the work of quality and quantity achieved by an employee in carrying out their duties in accordance with the responsibilities given to him. Meanwhile, according to (Bangun, 2012) said performance is the result of work achieved by someone based on job requirements, requirements commonly referred to as work standards, namely the level expected by a particular job to be completed and compared to the goals or targets to be achieved. From some of the above understanding it can be concluded that performance is a process of how the work takes place to achieve work results both in quality and quantity in accordance with the duties and responsibilities given to him. Furthermore, according to A. Dale Timple in(A. P. Mangkunegara \& Prabu, 2015), the factors that affect performance consist of internal factors and external factors. Internal factors are factors that are associated with the nature of a person, one of which is work discipline. while external factors are factors that affect the performance of someone who comes from the environment, one of which is supervision. Thus, it can be concluded that the factors that influence the achievement of performance include individual factors and organizational work environment factors.

\subsection{Theoretical Framework}

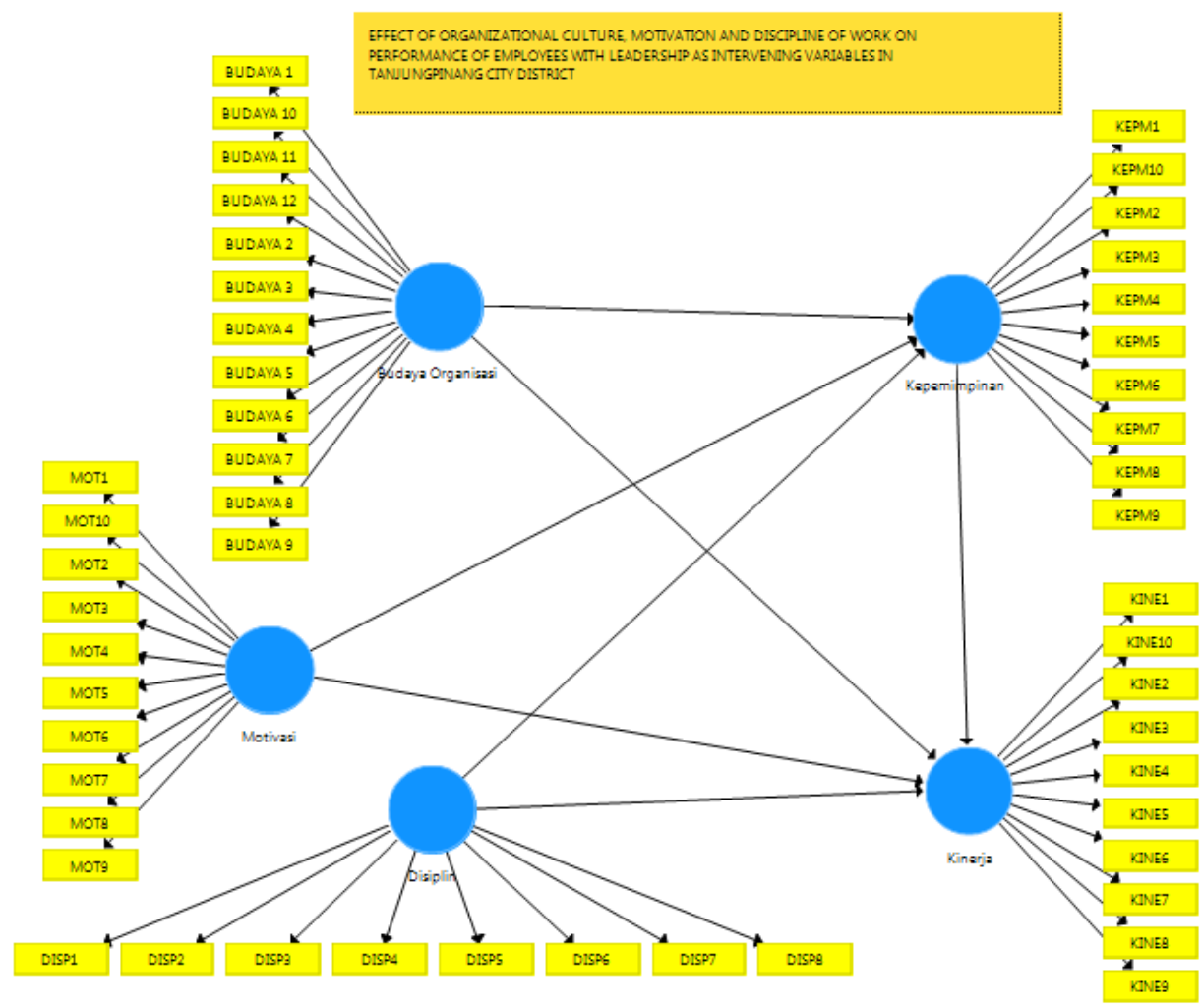




\subsection{Research Hypothesis}

Tentative statements (temporary) which are allegations or guesses about what researchers observe in an effort to understand them. There are hypotheses that must be disclosed regarding a clear structure that makes it easy to know the types of variables and the direction of the relationship between variables, whether positive or negative, a temporary answer to the research problem, is as follows:

1. Organizational Culture provides a direct influence on employee leadership in Tanjungpinang Kota sub-district

2. Motivation provides a direct effect directly on employee leadership in Tanjungpinang Kota sub-district

3. Discipline has a direct effect on employee leadership in Tanjungpinang Kota sub-district

4. Organizational Culture provides a direct effect on employee performance in the Tanjungpinang Kota sub-district

5. Motivation directly determines employee performance in the Tanjungpinang Kota sub-district

6. Discipline directly determines employee performance in Tanjungpinang Kota sub-district

7. Leadership determines directly the performance of employees in the Tanjungpinang Kota sub-district

\section{Research Method}

The location of the study was conducted at the Tanjungpinang Kota and Kelurahan District Offices located below.

\subsection{Population}

Population is a generalization of all subjects and objects of existing research. then the authors determine that the population in this study is the Tanjungpinang District and City Sub-District Office Employees who are below it with 95 employees.

\subsection{Sample}

Withdrawing sample members by sampling technique, the results are expected to be representative of the characteristics of the study population (representative). Researchers used data processing using SEM with PLS software version 3.2.9, in this study researchers used the census method, so that respondents who numbered 95 respondents had to fill out questionnaires that had been distributed.

\subsection{Data Collection Techniques}

For the purposes of the analysis of the problem under study, the data collection is carried out using techniques:

1. Interview, namely question and answer directly to the parties concerned to obtain the desired data and information.

2. Spread the questionnaire that contains questions from each research variable, where the number of questions from each of these variables is 5 questions. Then the questions are weighted based on a Likert scale with a weighting of values 1 to 5 .

3. Document Study, which is studying and observing data or reports contained in the Tanjungpinang District and City Sub-District Offices located below.

\subsection{Research Variables}

In this study the variables are divided into independent variables, namely influencing variables, consisting of (X1) Organizational Culture, (X2) Motivation, (X3) Discipline. The other variable is the dependent variable, which is the variable that is affected or which is the result due to the independent variable. In this study there are two dependent variables namely Intervening Variable (Y) Increased Leadership, and the dependent variable (Z) Performance.

\subsection{Data Analysis Techniques}

Data analysis was performed using the structural method Equation Model (SEM). Software used for analysis structural is to use the help of PLS (Partial Least Square software. In PLS Analysis usually uses two sub-models, namely the measurement model (outer model) is used for validity and reliability testing, while the structural model (inner model) is used for causality or hypothesis testing for predictive test models (Ghozali \& Latan, 2015). 


\section{Result and Discussion}

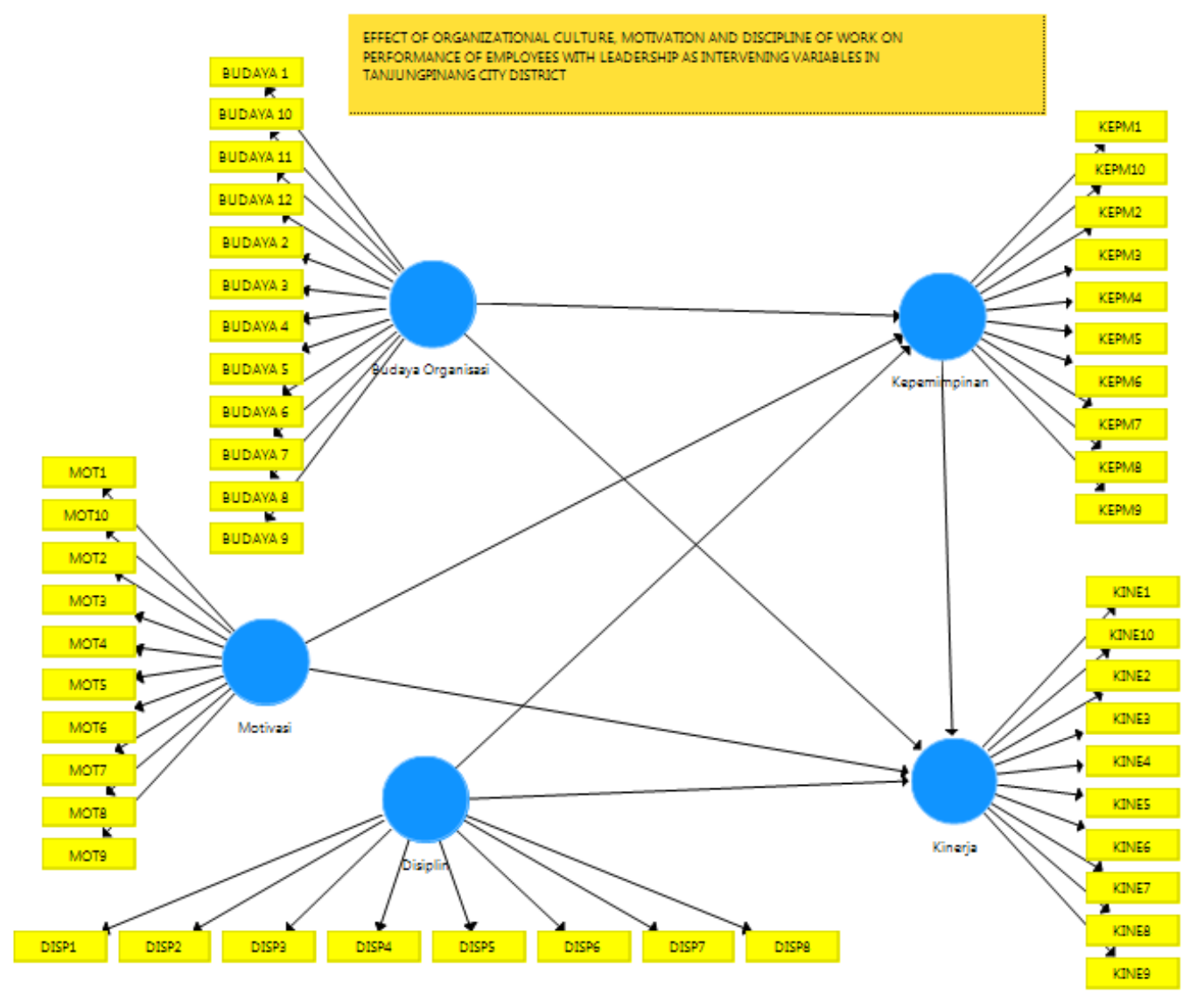

Table 1 Result For Inner Weights

\begin{tabular}{|l|c|c|c|c|c|}
\hline Konstruk & $\begin{array}{c}\text { Original } \\
\text { Sample (O) }\end{array}$ & $\begin{array}{c}\text { Sample Mean } \\
\text { (M) }\end{array}$ & $\begin{array}{c}\text { Standard } \\
\text { Deviation } \\
\text { (STDEV) }\end{array}$ & T Statistics & $\begin{array}{c}\text { P } \\
\text { Values }\end{array}$ \\
\hline Culture -> Leadership & 0,212 & 0,207 & 0,133 & 1,598 & 0,111 \\
\hline Motivation -> Leadership & 0,763 & 0,765 & 0,084 & 15,733 & 0,000 \\
\hline Discipline -> Leadership & $-0,357$ & $-0,357$ & 0,116 & 3,091 & 0,732 \\
\hline Culture -> Performance & 0,264 & 0,255 & 0,067 & 3,913 & 0,000 \\
\hline Motivation -> Performance & $-0,004$ & $-0,003$ & 0,057 & 0,079 & 0,937 \\
\hline Discipline -> Performance & 0,718 & 0,726 & 0,064 & 11,172 & 0,000 \\
\hline Leadership -> Performance & $-0,019$ & $-0,021$ & 0,054 & 0,342 & 0,732 \\
\hline
\end{tabular}

Table $2 \mathrm{R}^{2}$ Value for Endogenous Variables

\begin{tabular}{|l|c|}
\hline Endogenous Variables & R Square \\
\hline Leadership & 0.585 \\
\hline Performance & 0.890 \\
\hline
\end{tabular}

Source: Output PLS 3.2.9 Report (2020)

After theoretical discussion and research, the results of this study can be described as follows:

1) Based on the results of statistical calculations, it can be concluded that the construct of Organizational Culture has a positive but not significant effect on the construct of Leadership directly. This can be seen from the $t-$ statistic value smaller than 1.96 which is equal to 1.598 and p-value of 0.212 . Thus, the H1 hypothesis in this study was rejected. This result shows that the Organizational Culture variable does not have a significant direct effect on Leadership. The reason for rejecting this hypothesis is allegedly because an employee who has a high organizational culture does not always have a high leadership spirit towards his organization. According to what (Tampubolon, 2004) stated, organizational culture is a pattern of basic assumptions to act, determine or develop organizational members. in overcoming problems by adapting them from the outside and integrating them into the organization so that employees can work carefully, and also benefit new employees as a basis for 
correction of their perceptions, thoughts, and feelings in relationships to overcome problems.

2) Based on the results of statistical calculations, it can be concluded that the construct of motivation has a significant positive effect on the construct of organizational commitment directly. This can be seen from the tstatistic value greater than 1.96 which is equal to 15.733 . Thus, the H2 hypothesis in this study was accepted. This result shows that showing that motivation has a significant influence on leadership, this shows that an employee who has high motivation tends to have a good leadership spirit as well. This is according to (Hasibuan, 2012) that motivation is the provision of motive power that creates the excitement of one's work, so that they want to work together productively to achieve and realize the goals that have been determined.

3) Based on the results of statistical calculations, it can be concluded that the construct of work discipline has a significant positive effect on the construct of leadership directly. This can be seen from the t-statistic value greater than 1.96 which is 3.091. Thus, the H3 hypothesis in this study was accepted. These results show that when the Communication Style of employees working in the Tanjungpinang City Youth and Sports Office improves, the better the Culture of Employee Organization in the office and vice versa if an employee does not have a good Communication Style, then the Culture of Employee Organization will be low. This is in accordance with the theory of Communication Style (Sule \& Priansa, 2018) states that in general the style is an attitude, movement, behavior, and gestures summarized in the human personality in this case a leader in an organization.

4) Based on the results of statistical calculations, it can be concluded that the construct of Organizational Culture has a significant positive effect on the construct of Employee Performance directly. This can be seen from the t-statistic value greater than 1.96 which is 3,913 . Thus, the H4 hypothesis in this study was accepted. These results indicate that there is a significant influence between organizational culture on performance. This shows that an employee who has a high organizational culture is likely to have a high performance also on his organization. This is in accordance with the theory revealed by (Melina Taurisa \& Intan, 2012) that Organizational Culture represents a common perception of the members of the organization. Therefore, it is expected that individuals who have different backgrounds or are at different levels in the organization can understand the culture of the organization with similar understandings and have the same goals for the sustainability of the organization.

5) Based on the results of statistical calculations, it can be concluded that the construct of motivation has a positive but not significant effect on the construct of employee performance directly. This can be seen from the tstatistic value smaller than 1.96 which is equal to 0.079 and p-value -0.004 . Thus, the H5 hypothesis in this study was rejected. These results indicate that motivation does not have a significant direct effect on employee performance. The reason for rejecting this hypothesis is allegedly because not all employees who work have great motivation to achieve good performance this can be caused by not fulfilling the physiological needs of employees at work, a sense of security at work, social needs, self-esteem needs and self-actualization needs. In accordance with the theory put forward by (Sutrischastini \& Riyanto, 2015) argues that motivation is the provision of motive power that creates the excitement of one's work, so that they are willing to work together productively to achieve and realize the specified goals.

6) Based on the results of statistical calculations, it can be concluded that the construct of work discipline has a significant positive effect on the construct of employee performance directly. This can be seen from the tstatistic value greater than 1.96 which is 11,172 . Thus, the H6 hypothesis in this study was accepted. This result shows that this shows that an employee who has a high Work Discipline is likely to have a high performance of the organization. This is in accordance with the theory put forward by (Hasibuan, 2012) argues that discipline is an operative function sixth from Human Resource Management. Discipline is the most important HRM operative function because the better employee discipline, the higher the work performance that can be achieved.

7) Based on the results of statistical calculations, it can be concluded that the construct of leadership has a positive but not significant effect on the construct of performance directly. This can be seen from the t-statistic value smaller than 1.96 which is equal to 0.342 and p-value of 0.732 . Thus, the H1 hypothesis in this study was rejected. These results indicate that an employee who has high leadership does not always have a good performance on the organization because there are many factors that influence a person's leadership on his performance including the factors of group interest. This is in accordance with the theory put forward by (Rivai \& Mulyadi, 2003), leadership is basically involving others, involving uneven distribution of power between leaders and group members, mobilizing abilities by using various forms of power to influence the behavior of subordinates, and concerning value.

\section{Conclusion}

After theoretical discussion and research, the results of this study can be concluded as follows:

1. Influence of organizational Culture latent variables on Leadership latent variables has a t-statistic value in this construct relationship is 1.598 and p-value 0.111 . indicates that the effect of Organizational Cultural latent 
variables on Leadership latent variables is not positively significant.

2. The effect of latent variables Motivation on Leadership as evidenced by the significant value of the t-statistic value in this construct relationship is $15.733>1.96$ and the p-value of 0.000 indicates that the effect of the latent variable Motivation on Leadership is significantly positive.

3. The effect of latent variables Work Discipline on Leadership as evidenced by the t-statistic value in this construct relationship is 3.097 and the p-value of 0,732 . indicates that the effect of the Work Discipline variable on Leadership is significantly positive.

4. The influence of organizational culture latent variables on Employee Performance as evidenced by the significant value of the t-statistic value in this construct relationship is 3.913>1.96 and the p-value of 0.000 indicates that the influence of organizational culture latent variables on Performance is significantly positive.

5. Effect of latent variables Motivation on Performance as evidenced by the t-statistic value in this construct relationship is $0.079<1.96$ and a p-value of 0.937 indicates that the effect of latent variables on Motivation on Performance is not positively significant.

6. Effect of latent variables Work Discipline on Employee Performance as evidenced by the t-statistic value in this construct relationship is $11,172>1.96$ and a p-value of 0,000 indicates that the effect of latent variables Work Discipline on Performance is significantly positive.

7. Influence of Leadership latent variables on Employee Performance as evidenced by the t-statistic value in this construct relationship is $0.342<1.96$ and the p-value of 0.732 indicates that the influence of Leadership latent variables on Work is not significant positive.

8. Performance Change is influenced by Organizational Culture, Motivation and Discipline by $89.0 \%$. While the change in Leadership is influenced by Organizational Culture, Motivation and Discipline by $58.5 \%$.

\section{References}

Bangun, W. (2012). Manajemen Sumber Daya Manusia, Jakarta: PT. Glora Aksara Pratama.

Ghozali, I., \& Latan, H. (2015). Partial Least Squares, konsep, teknik dan aplikasi menggunakan program Smartpls 3.0 untuk penelitian empiris. Semarang: Badan Penerbit UNDIP.

Hasibuan, M. S. P. (2012). Manajemen sumber daya manusia Jakarta: Bumi Aksara.

Keith, D. (2010). Terjemahan Agus Dharma. Perilaku Dalam Organisasi. Jakarta: Erlangga.

Mangkunegara, A. A. A. P. (2016). Manajemen sumber daya manusia perusahaan. PT. Remaja Rosdakarya.

Mangkunegara, A. P., \& Prabu, A. (2015). Manajemen Sumber Daya Manusia Perusahaan, Cetakan kedua belas. Penerbit PT. Remaja Rosda Karya Offset, Bandung.

Melina Taurisa, C., \& Intan, R. (2012). Analisis pengaruh budaya organisasi dan kepuasan kerja terhadap komitmen organisasional dalam meningkatkan kinerja karyawan (Studi pada PT. Sido Muncul Kaligawe Semarang). Jurnal Bisnis Dan Ekonomi, 19(2).

Rivai, V., \& Mulyadi, D. (2003). Kepemimpinan dan perilaku organisasi. Jakarta: Raja Grafindo Persada.

Sule, E. T., \& Priansa, D. J. (2018). Kepemimpinan dan Perilaku Organisasi. Bandung: PT Refika Aditama.

Sutrischastini, A., \& Riyanto, A. (2015). Pengaruh motivasi kerja terhadap kinerja pegawai kantor sekretariat daerah Kabupaten Gunungkidul. Kajian Bisnis Sekolah Tinggi Ilmu Ekonomi Widya Wiwaha, 23(2), 121137.

Sutrisno, E. (2010). Manajemen Sumber Daya Manusia, ed. I, cet. II. Kencana, Jakarta.

Tampubolon, M. P. (2004). Perilaku keorganisasian. Jakarta: Ghalia Indonesia. 